\title{
Social Identity Complexity Theory as heuristic tool in New Testament Studies
}

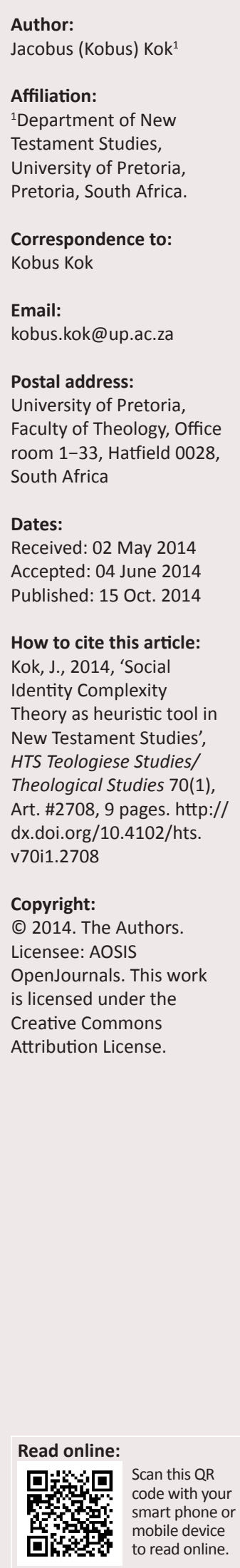

In this article the author gives an overview of a relatively new theory in social psychology, namely Social Identity Complexity Theory, and illustrates the heuristic value of the theory for New Testament interpretation. Paul's letter to the Galatians is taken as a case study to illustrate how the theory could shed new light on the Galatian conflict and on Paul's social identity complexity, which might have made him a good facilitator of change and reconciliation.

\section{Introduction}

The main purpose of this article is to introduce the value of Social Identity Complexity Theory (from here on SIC) for the interpretation of New Testament texts.

This article will be structured as follows:

- Firstly, we will provide the theoretical framework in which an overview of SIC theory will be presented, which will be the heuristic lens we will use to interpret the selected New Testament case study.

- Secondly, we will turn to an analysis of a selection of biblical material, with specific reference to Paul's letter to the Galatians as case study. First we will illustrate how the ancient Judeans drew social boundaries, but how the implicit ethics of the remembered Jesus facilitated the responsibility for reconciliation and transcendence of social boundaries for early Christfollowers. SIC theory will be used to explain how people like Paul, inspired by Jesus, transcended social boundaries and facilitated reconciliation.

\section{Methodological approach: Social identity complexity - an overview}

In what follows, I will briefly give an overview of SIC theory and its potential value as heuristic tool for New Testament interpretation.

In the past (cf. Esler 2003) and as recent as in 2014 (Tucker \& Baker 2014), Social Identity and Social Categorisation Theory was used fruitfully by New Testament scholars to explain ancient group dynamics and identity construction. The problem is that Social Identity Theory (from here on SIT) does not deal with multiple group memberships, or identity construction that changes over time. In recent years, several scholars like Elliott (2007:119-154) have illustrated the fluidity

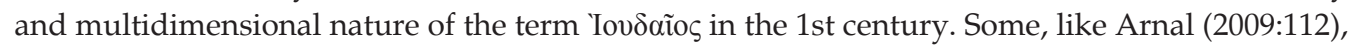
argue that many scholars today would point out that: 'Judaism is today, and apparently was in antiquity, a visible multivalent fusion of a wide range of identity-markers and ways of conceptualizing identity.' It thus seems that ancient Jewish and Christian identity was much more complex than we used to think. Nowadays, scholars are increasingly warning against reducing ancient Judaism to some monolithic, essentialist entity. Another problem, as Kok and Roth (2014) have argued, is that we often speak of ancient Christian identity as if 'Christian' identity was some 'fixed' identity. Perhaps it was much more complicated than we tend to think.

The question could be asked whether SIT is able to account for the complexity and multidimensional nature of ancient Christian identity construction? In social-psychology, especially in studies on group processes, some scholars have in the last decade or so, been working on the so-called Social Identity Complexity Theory which, as a heuristic tool, would be able to account for the dynamic multifaceted nature of ancient Christian identity. In the following, I will provide a brief overview of this rather new theoretical construct, and in doing so, heavily draw on an article by Roccas and Brewer (2002), who are leading exponents in this regard.

Roccas and Brewer (2002:88) ${ }^{1}$ argue that the vast majority of research on intergroup relations in the past have centred on single ingroup-outgroup categorisation. Similarly, in New Testament 1.Also see Schmid and Hewstone (2011:77-102). 
studies, where SIT was used, this has been the case. However, an increasing amount of scholars nowadays recognise the phenomenon that people can belong to several different groups at the same time; people could hold multiple social identities. What these scholars have now investigated is what influence multiple group categorisation might have on ingroup bias and the perception and evaluation of other people and groups. Different people represent their multiple social identities in different ways. Within the same group for instance, there might be people who simultaneously belong to particular groups each of a different nature (intimacy groups, loose associations, religious groups, and so forth), but in their own mind, and in a particular context, they might view a certain group (and loyalty to that group) as being more important than another group. In other words, in every individual there is some form of (fluid) hierarchy according to which the importance or dominance of certain groups is structured in a certain way at a certain point in time, depending on the unique dynamics of the context. After all, people are not 'static' but change all the time. The way that the hierarchy of multiple group categorisation is now, might in future, or in another context, be different.

Some people have many different groups they belong to, and others have only a few. There are also many ways in which the relationship between these groups may be structured. Some of these ways are more complex than others. Roccas and Brewer's (2002) research has shown that people who have a high level of social identity complexity are less likely to show negative attitudes towards outsiders. For this reason, it is important for us to reflect on the structure of multiple social identities, because 'representations of one's ingroups have effects not only on the self-concept but also on the nature of relationships between self and others' (Roccas \& Brewer 2002:88). But before we discuss this matter in more detail, let us first have a look at the different ways multiple group loyalties or multiple group categories might be structured and represented by individuals.

One important aspect that Roccas and Brewer (2002:89) investigate is the degree of overlap between different social categories in the subjective representation of a person's multiple group loyalties. There is also in some contexts an objective degree of overlap. It is sometimes the case that particular groups are in fact heavily embedded within each other. In the past, for instance during the Great Trek (1838) in South Africa, being an Afrikaner was synonymous with being a Reformed or Calvinistic oriented Christian. In a situation where there is a high degree of overlap between different in-groups, identification is simple, out-groups easily identified, and such a person or group's social identity complexity rather low in nature. When a person who is white, Afrikaans and Christian, sees only other white Afrikaans Christians as ingroup members, she has a rather simplified social identity complexity and excludes many people in the process. For instance, there might be many white Afrikaners who are not Christian or many black Africans who might be Christian.
From another perspective, multiple in-groups can also be presented subjectively or objectively in ways in which the overlap between the different groups is only partial in nature. Roccas and Brewer (2002:89) point out that when someone avoids reducing the subjective inclusiveness of in-groups in a simplified manner as previously, but rather recognise the fact that ingroup identities do not converge or overlap, then her social identity is more complex and inclusive in nature. Such people tend to be less likely to illustrate 'fundamentalistic' ingroup bias, and tend to be more inclusive (Roccas \& Brewer 2002:89). The reason is that they have the ability to deal with complexity in their own social identity and tend to be more understanding of outgoups. There are many different ways in which multiple ingroup representation could be structured. Roccas and Brewer (2002:90) explain at least four models of identity representation:

\section{Intersection}

By means of intersection, an individual can have simultaneous recognition of multiple social identities, but in the process maintain a single ingroup representation by defining the ingroup as the intersection of the multiple in-groups. For instance, when an Afrikaans person defines his or her primary social identity as being Afrikaans and living in the rich suburbs of Pretoria East, she constructs a compound identity shared only with other Afrikaans people living in the rich eastern suburbs of Pretoria. We could see that this compound identity is rather unique and by implication excluding a lot of people who are also Afrikaans, but live in other areas or countries, for instance. Those who do not share these identity markers are seen as belonging to the out-group. This way of representing social identity is said to follow a social exclusion pattern, as a result of the exclusive nature of the constructed ingroup boundaries or categories (Roccas \& Brewer 2002:90). Only at the point where the two social groups intersect are ingroup members defined as such. Consequently, those who belong to the broad categories of the group, but do not share that specific intersection, are labelled as outgoup members. Clearly, this way of constructing social identity is not very complex and people who do that are less likely to be inclusive in nature. Such people would rather tend to be exclusive and less likely to transcend social boundaries (Roccas \& Brewer 2002:90) (Figure 1).

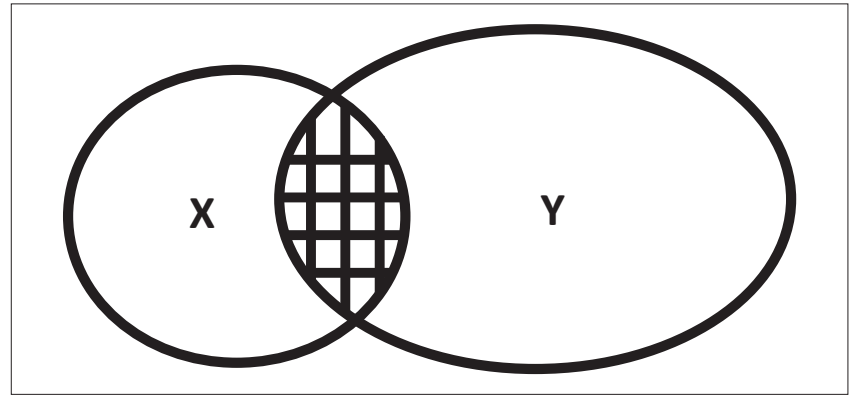

Adapted from Roccas, S., \& Brewer, M.B., 2002, 'Social identity complexity', Personality and Social Psychology Review 6(2), 88-106. http://dx.doi.org/10.1207/S15327957PSPR0602_01 FIGURE 1: Intersection. 


\section{Dominance}

Another strategy of dealing or coping with different (competing) social identities is to make one of the identities the dominant one, and construct all others in a subordinate relationship to the dominant social category. Roccas and Brewer (2002) explain:

In this model, the ingroup is defined as those who share membership in this primary ingroup category; all other category memberships are essentially not social identities at all but simply aspects of the self as a member of the primary group. In other words, alternative social identities are embedded within the primary group identifications (as sources of intragroup variation) but not extended to those outside that ingroup. (p. 90)

Graphically, it could be illustrated as shown in Figure 2.

An example could be used: A female minister of a church, who views her professional identity as minister of church as her primary social identity, will view all other ministers of church as ingroup members. The fact that she is a woman, or studied at the prestigious university of Oxford are simply side-line characteristics of the kind of minister of a church she is, which is the dominant social category. In other words, her social identity is not extended to women or Oxford graduates in general, for instance. So, when one particular social identity is dominant, it takes precedence over all others and such people will subsequently categorise other people broadly in terms of that particular social category. Those who belong to that broad social category are seen as insiders and those who do not belong to that group will be seen as outsiders, even if outgroup members

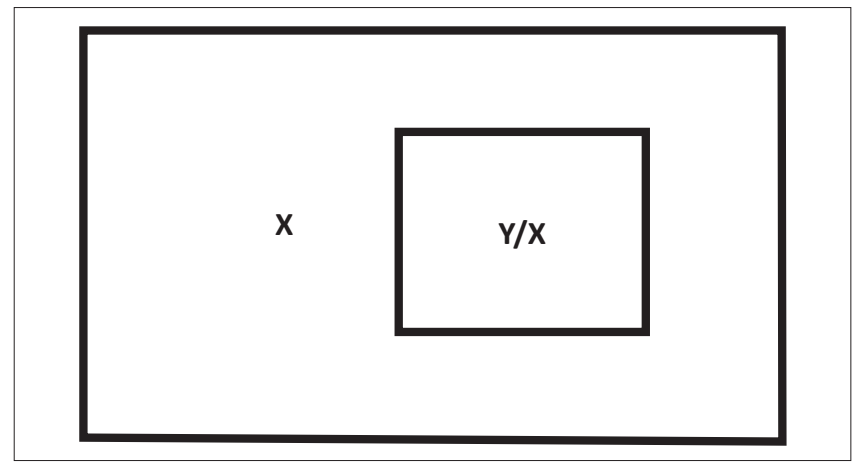

Adapted from Roccas, S., \& Brewer, M.B., 2002, 'Social identity complexity', Personality and Social Psychology Review 6(2), 88-106. http://dx.doi.org/10.1207/S15327957PSPR0602_01 FIGURE 2: Dominance.

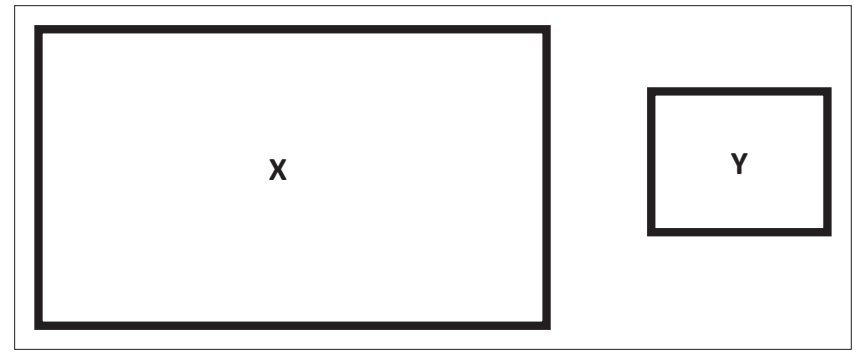

Adapted from Roccas, S., \& Brewer, M.B., 2002, 'Social identity complexity', Personality and Social Psychology Review 6(2), 88-106. http://dx.doi.org/10.1207/S15327957PSPR0602_01 FIGURE 3: Compartmentalisation. happen to be woman who studied at Oxford. Such a person would rather identify with men who are ministers than women who studied at Oxford but are not ministers. Thus, one social category is very dominant in this model.

\section{Compartmentalisation}

It may also happen that a person could have multiple social groups that are important to the individual and which shapes and determines that person's social identity. In such a case, compartmentalisation is one strategy a person could use to manage these different and sometimes even competing social identities. With compartmentalisation, a person would activate multiple identities and express those identities contextually in a process of isolation and differentiation (Roccas \& Brewer 2002:90). Consequently, the context determines which identity will be the primary basis for social identity. A person could thus oscillate between different social identities according to the demands of the social context. The well-known African scholar John Mbithi, as told by my colleague Dr. Elijah Mahlangu, once said that 'Africans are Christians by day and traditionalists by night'. This illustrates the problem or reality of compartmentalisation. I often use the example of a former student of mine who is the son of a traditional Zulu African chief, but also a successful businessman in a corporate context in the city in South Africa. He tells of his internal struggle when he has to 'oscillate' between his different identities that in many ways do not always overlap. When he goes home to his father in the rural mountainous areas in Natal, he has to 'take off his Western thinking hat' and 'put on his African hat'. Roccas and Brewer (2002:91) explain that 'With this mode of identity structure, multiple nonconvergent identities are maintained, but the individual does not activate these social identities simultaneously'; the context determines which one will be more salient (Roccas \& Brewer 2002:90) (Figure 3).

Not only are the identities activated contextually, but they are often mutually exclusive (Roccas \& Brewer 2002:91). The interesting nature of the group dynamics is that in a specific context, where a particular social identity is activated and more dominant, a person might treat others, who in another context might be ingroup members, as outgroup members. Thus, the situation or context determines the boundary lines between identities which are to a large extent mutually exclusive in nature. ${ }^{2}$ In their research, Roccas and Brewer (2002) have found that people who make use of this strategy will often tend to respond more positively to people who share both ingroup identities than to people who share only in one of these social categories and more negatively (or exclusively) towards people who do not share one of these ingroup categories.

\section{Merger}

The final representation model Roccas and Brewer (2002:91) discuss is the so-called merger model. In this model 'non2.Cf. Peter in Galatians: One moment he eats with Paul's people in Antioch and the next he withdraws and makes another social identity more dominant. 


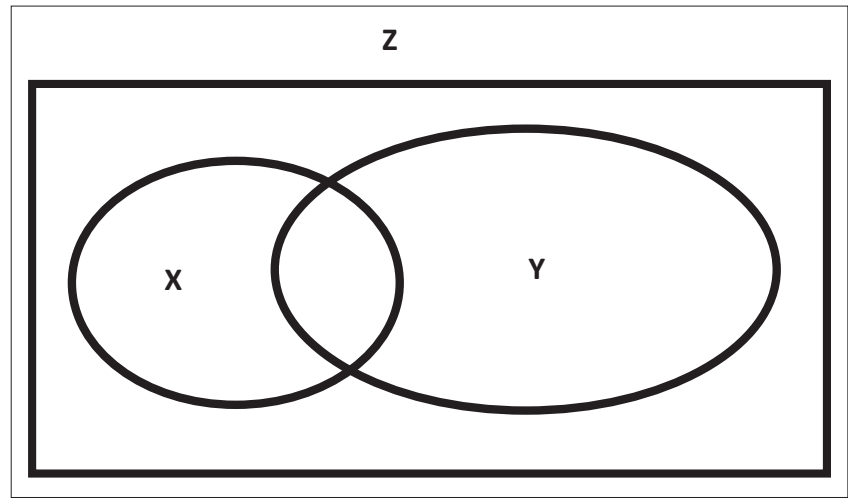

Adapted from Roccas, S., \& Brewer, M.B., 2002, 'Social identity complexity', Personality and Social Psychology Review 6(2), 88-106. http://dx.doi.org/10.1207/S15327957PSPR0602_01 FIGURE 4: Merger.

convergent group memberships are simultaneously recognized and embraced in their most inclusive form' (Figure 4).

In this social identity representation model, people who share any of a person's in-group memberships are seen or identified as belonging to the ingroup. When a female minister of a church (Christian) who studied at Oxford extends her social identity in a way that all people who are Christian are included, for instance, such a person's social identity is the sum of the combined group categories. This entails that this woman's identification with other women as a social category transcends the boundary of ministers of church ánd non-ministers of church, her identification with ministers of church transcends the gender boundary line, and her identification with scholars from Oxford transcends the disciplinary boundary line, for example. In other words, the sum of her merged ingroup identities leads to an inclusive and diverse social identity which is rather complex and transcending in nature. Roccas and Brewer (2002:91) correctly state that: 'In this mode, social identity transcends single categorical divisions between people ... [T] he more social identities the person has, the more inclusive the definition of ingroup becomes ...' Cognitive consistency theorists would describe the merger model as being analogous to 'transcendence', according to Roccas and Brewer (2009:91), which relates to the introduction of some superordinate principle that makes the inconsistent cognitions compatible'. This brings us to the issue of social identity complexity as Roccas and Brewer (2002:91) explain: All these models described above are strategies of 'inconsistency resolution' and tend to be either more or less cognitively complex in nature. A person who is high in social identity complexity will be more inclined to differentiate and integrate conflicting points of view. When diversity or differentiation is suppressed or denied, the complexity is simplified, thus resulting in a lower social identity complexity. Obviously, the first model discussed previously (differentiation) is the less complex in nature. This model suppresses inconsistencies by reducing the complexity of it to a simplified and highly exclusive social ingroup identity construction.

Dominance as strategy would also count as a rather simplified model, in the sense that it also simply suppresses inconsistency and has a particular social category dominating the others. Inconsistencies are thus denied by suppression and domination. Compartmentalisation would score a little higher on the ranking of social identity complexity given that this approach does recognise the complexity and inconsistencies, but the only problem is that by keeping the categories separate, these conflicting identities are not really reconciled or integrated but rather kept separate. Consequently, as Roccas and Brewer (2002:92) argue, the merger model could be interpreted as representing the most complexity for two reasons: (1) firstly, it recognises the opposing or even mutually excluding social identities, but (2) it aims to not only differentiate, but also integrate them in an inclusive social identity. An important observation of the aforementioned researchers is that the nature of the social categories can also influence the level of complexity. For instance, when a dominant social identity represents a group that is rather small by implication, for instance Afrikaners staying in the rich eastern suburbs of Pretoria, that model could be less complex than a model of intersection which by implication has categories which are more inclusive in nature.

In this sense, domination, which is basically more complex in nature than intersection, could actually be less inclusive. Suffice to say, this is also true for compartmentalisation; a person who has highly compartmentalised identities might express or represent them in a particular context in such a way that it is very exclusive and dominating. Such a form of compartmentalisation could be even less inclusive than other forms of dominance, for instance (Table 1).

On the other hand, when a strategy like compartmentalisation is low in nature and the different categories are too fluid and 'spill over' into the different domains, this model could in practice function like a merger model, but in fact it is not, because an integrated and complex identity that transcends boundaries is not really represented (Roccas \& Brewer 2002:92). Finally, a very important observation is made by Roccas and Brewer (2002:92) and that is that 'individuals may adopt different modes of identity representation at different times...' In times of radical change or stress, a person who is normally high in social identity complexity representation (merger model) might resort to domination, for instance. This might also be true for groups who are at times highly differentiated and accommodating in nature, but in times of crisis draw stronger boundaries and resort to compartmentalisation, dominance or even intersection. When the Old and New Testaments are studied from a socialhistorical and diachronic point of view, a case could be made that there is clear indication of these tendencies at different times. At times the Christian movement was very inclusive

TABLE 1: Degree of social identity complexity.

\begin{tabular}{ll}
\hline Model: Strategy of managing complexity & Degree of complexity \\
\hline Intersection & Lowest in social identity complexity \\
Dominance & Low in social identity complexity \\
Compartmentalisation & Higher in social identity complexity \\
Merger & Highest in social identity complexity \\
\hline
\end{tabular}


in nature, accommodating and integrating diversity, but at other times it was more exclusive in nature and illustrated or expressed that in clear linguistic ways.

\section{Analysing the past: Drawing and transcending boundaries in antiquity \\ Social identity complexity and the transcendence of boundaries in the New Testament}

\section{Ancient Jews and strict boundary lines}

New Testament scholars who approach the New Testament from a social-scientific perspective point to the fact that ancient Mediterranean people were strongly grouporiented individuals (Kok \& Van Eck 2012). Consequently, the group played a very important or dominating role in the social identity of a person. In such a society, clear boundary lines existed between the in-group and out-groups. In fact, by saying that you belonged to one particular group, like the Jews, by implication meant that you had inclusive and exclusive social boundaries: inclusive boundaries are shared with society and exclusive boundaries are not shared with society, and functions as identity markers to the outside (Wolter 2006:200-201). Social boundaries are fluid and change over the course of time in response to social changes. So, when dealing with the New Testament, the question would be how the Judeans in the time of Paul might have constructed their distinct sense of self. Formulated in a question: How did the Judeans of Paul's day understand their own identity and how did 'outsiders' perceive them?

As mentioned previously, in the group oriented ancient world, boundaries were created between in-groups and out-groups. People who belonged to the out-group were mostly viewed with suspicion. Although recent studies illustrate the pluriformity of ancient Judaism, a strong case is made by some scholars that 'the self-assured Judaism in the Diaspora largely resisted assimilation to the pagan world and developed forms of an independent Jewish identity distinct from its surroundings' (Frey 2012:64). It does seem that some Jews who lived in the Diaspora held on to their Jewish ways in an effort to maintain their identity as a people who are called by God to be holy and a light unto the nations (cf. Lv 19:2). There are also some primary ancient sources that indicate that the Jews distanced themselves from participating in some elements in the public and social life of the Roman Empire as evident in/expressed in some socioreligious rules like eating habits, and so forth (Frey 2012:65) (cf. Jos. C. Ap. II, 210; Jos. Ant. XX, 17-96 referred to by Frey 2012:65). Frey (2012) particularly refers to the evidence of clear delimitation (in contrast to assimilation), for instance in the way Jewish dietary laws inhibited or even restricted social interaction with non-Jews on that social level.

Secondly, sexual intercourse and marriage with nonJews was mostly seen in a negative light (cf. Jos. Ant. XX,
$139,145 f$.). This shows us that from a certain point of view it is clear that at least some Jews in the time of Paul employed clear boundary maintenance strategies. This would have influenced the social identity of Jews and would have been expressed in favouritism towards those who belonged to the in-group (Malina \& Rohrbaugh 1992:2). In the New Testament, we explicitly see how this might have functioned when we investigate John 4:1-42, where Jesus is presented as initiating social interaction with a Samaritan woman. In the narrative, Jesus talks to her and he asks her for something to drink (Jn 4:7). The Samaritan woman is presented by John as the one that 'reminds' Jesus of the boundary lines that inhibited or even prohibited the interaction on such a level between Jewish men and Samaritan women. The Samaritan woman asks Jesus: 'How is it that you, a Jew (Ioudaios), ask a drink of me, a woman of Samaria? For Jews have no dealings with Samaritans' (Jn 4:9). Jesus keeps on initiating the interaction and transcends the social, religious and cultural boundaries that have kept Jews and Samaritans apart for centuries. Jesus was a bridge builder, someone who engaged in interaction with people whom traditional Jews of the day would have rejected (Lk 15:1). When John or the community responsible for writing John's Gospel does so, this is the boundary-transcending Jesus they remembered (see Kok 2008).

In the Jewish (Judean) conceptual world, the world existed with the Jews on the one hand and all the rest of the nations on the other. Their Jewish identity and covenant relationship with God, which was defined in terms of holiness and being set apart, dominated their worldview and the way in which they structured their relationships with out-groups. The conceptual world of the temple-oriented Jews was concentric in nature (see Neyrey 1991:132, 278-279; Kok 2008:120). The term Ioudaioi was used by insiders and outsiders to describe the people who belonged to the land Judea and its most central symbol, the temple. In the Diaspora, as Donald Binder in Esler (2003:ad loc 1026 of 7087) indicated from all over the world, money (first fruit) was sent to the temple in Jerusalem, and synagogues were built in such a way that it faced the temple in Jerusalem. So, all over the world, the Jews felt themselves connected to the land of Judea and its temple. In times of feasts, pilgrims from all over would stream to Jerusalem. In foreign countries, these people did not lose their distinct sense of identity and their connection to their country of origin. For this reason Esler (2003:ad loc 1056 of 7087) translates Ioudaioi with Judeans, to keep the connection to the land explicit, which I will also do in this article. In the ancient world, ethnic groups were connected to their homeland. This is most clearly seen in Josephus (Jewish wars 2.43), who refers to Jews from different areas as 'Judeans' (Ioudaioi), explicitly linking the people with the land and temple.

According to social identity and social categorisation theory, groups exist by virtue of the fact that there are perceived out-groups (Trebilco 2013). A person's social identity is that part of one's self that is a result of one's membership in a group. People can belong to many 
different groups at the same time, but not all groups are of the same importance as we have seen previously. In the ancient world, the ethnic identity of Judeans was the primary or dominating identity and closely related to religious identity. In the process of constructing boundaries, stereotypical images of out-groups are constructed and presented. In the ancient world, there were many conflicts between Judeans and other ethnic groups as Christopher Stanley, in Esler (2003:ad loc. 1177), illustrated. One of the most well-known conflicts between Greeks and Judeans happened in the Alexandrian conflict in Egypt (38-41), as retold by ancient historians. Here we clearly see the social categorisation and conflict that SIT describes. The ancient world was riddled with ethnic boundaries and conflict. The Judeans as a people saw themselves as having been set apart by God (Lv19), and expressed that in their social interactions, as vividly illustrated in their dietary laws for instance.

From a social identity complexity perspective, it could be argued that the ancient Judeans were rather low in social identity complexity. Their social identity was constructed in strong opposition to out-groups. Strict social boundaries distinguished them from outsiders. Their religious identity was the most dominant identity of all and overshadowed and infiltrated their whole lives. Ancient authors recall that even in the Diaspora, the Judeans could be distinguished by the fact that they were circumcised, held certain eating habits and had many rituals that maintained a sense of identity of 'separateness' or being set apart as well as an explicit link to the Promised Land and the temple.

In the early years the Christ-following movement was an inner-Judean movement. In Acts 3:1 we read that the early Christ-followers, and their leaders in particular, kept on going to the temple, even after the death of Jesus. They did not stop being Judeans, that is, becoming 'Christians' did not mean converting to some new religion. Jesus was a Jew from birth to death, and so were Peter, John and James. However, being a Christ-follower also put those same Jews in a rather awkward position seeing as their theological claims were not accepted by all Jews as we see in the many instances of conflict reflected in the New Testament. As more and more non-Judeans or Hellenists joined the movement, and the exclusive Judean boundary markers came under pressure, so did the internal plurality and tension within the Christmovement increase. Subsequently, we find in Peter evidence of the internal struggle in which he found himself, which was symptomatic of the Christ-following movement as a whole, as we will now continue to explain.

\section{Peter's compartmentalisation as problem}

In Acts and in Galatians, Peter is presented as one of the leaders of the early Church (Gl 2:3, 6, 9). Peter was a Jew. Peter was also a prominent leader of the mainly ethnic Judean section of the Christ-following movement. As leader in a group-oriented world, Peter had to be very sensitive to the values of the group to which he belonged. As a Judean, Peter knew the dietary laws of the Jews according to which a Judean would not sit at the same table with non-Jews. This social reality was regulated by Jewish law. For the Jews the world was ethnocentrically divided between us and them, between insiders and all the rest. When we project our etic view back into the first century we tend to think that the early Christians broke with all the Jewish laws. That was not the case.

In the primary texts, we read that the parting with the ways was rather a more gradual process.

In Jerusalem, at the Apostle conference in 48/49 AD. Paul and the Jerusalem apostles reached an agreement that it would not be necessary for Gentile converts to be circumcised (Ac 15) and that they would endorse the ministry of Paul to the Gentiles (Hansen 2010:69). If they had not reached this agreement, there would probably have been two separate Christian churches; a Jewish Church headed by Peter, James and John and a gentile Church, headed by Paul. It is of course a question how those at the meeting envisioned the practicalities of the agreement. At that stage in history Gentile converts were still in the minority. The movement consisted predominantly out of Jewish Christ-followers. The Jerusalem agreement might have implied two ways of enacting the practicality of the matter. On the one hand, the expectation might have existed that Gentile converts would be welcomed in the circle of the Judeans for instance at table fellowship, without the requirement that they should have been circumcised. But did that mean that Jewish Christfollowers were also allowed to eat and have table fellowship with non-Jews? For one thing, some of the earliest letters of Paul, namely Galatians, illustrate that this matter might not have been so clear at that stage in history.

When Peter visited Paul in Antioch, probably shortly after the Apostle conference in Jerusalem, he initially seems to have had table fellowship with gentile believers (G1 2:14). But when those from Jerusalem, who were associated with James the brother of Jesus, came up to Antioch, Peter immediately separated himselffrom the non-Jews, an action associated with an exclusive and dominating social identity, typical of Judaism at the time (cf. Lv 17:10-15). From a Jewish social identity complexity perspective the rules are rather clear; Jews do not engage in table fellowship with non-Jews, because of the potential threat that might have for the strict Jewish purity laws. As said before, perhaps the Jerusalem meeting opened the doors for the non-Jewish believers to eat with Jewish believers on their (Jewish) terms.

The question, however, is whether this also went the other way around? It does seem that the former was perhaps the way in which the Jewish Christians in Jerusalem envisioned the process. This might explain Peter's behaviour in Antioch. At one moment in Antioch, Peter could engage in interaction with non-Judeans according to the needs of the context, illustrating some evidence of social identity complexity and inclusivity that went beyond the Jewish exclusive social identity expressions. But when pressure from the dominant mother church in Jerusalem came in the 
form of its representatives visiting Antioch, Peter suddenly retreated back to another exclusive social position. Clearly one way of being and doing was in opposition to another way of being and doing, and Peter in a sense seems to have compartmentalised his social identity according to the needs of the context. One moment he could act as the inclusive 'Antiochean Peter' and the next he acted as the exclusive ethnocentric 'Jerusalem Peter' which seems to have been the dominant (default) identity at that point in time. When the pressure was on, Peter illustrated the implicit hierarchy in his own social identity. Peter could have used the opportunity to correct the Judean representatives, or facilitated a middle ground, but he did not! Peter rather chose to Judiasein - to have his Judean identity play the dominant role with the implication that he suddenly excluded those he socialised with previously, and drew social boundaries between himself and them.

This action by Peter was a source of frustration to Paul who had a problem with this particular form of contextual compartmentalisation, which implicitly functioned in a dominating and non-inclusive way. The problem with Peter's action was that instead of embodying the transcendence of social boundaries Paul saw as essential to the inclusive nature of the gospel, Peter actually just reinforced the old exclusive and distinguishing boundaries between insiders and outsiders. Paul saw Peter's actions as being contradictory and mutually exclusive. In fact, it comes down to two forms of social identity, which according to Paul is mutually exclusive or dominating and does not enhance solidarity, unity and reconciliation. By separating himself from the Antioch non-Jews, Peter illustrated something of the irreconcilability of the two self-positions when it comes to social boundaries and the maintenance of those boundaries. Paul felt that this kind of compartmentalisation is wrong and went against the grain of the Christ-movement and the revelation he had received. Paul's argument is that one cannot be and live in a certain way now and suddenly do the exact opposite (G1 2:14).

\section{Paul's embodiment of integration and social identity complexity, expressed in the transcendence of social boundaries}

In the beginning years of the Christian movement, it was still part of Judaism in the sense that the movement as such developed as a movement within Judaism, as mentioned previously. In later years, especially when Paul came on the scene, more and more non-Judeans came to conversion. Paul's voice of inclusivity was thus a voice from the margin in a movement that was in a sense already a movement on the margins. At the early stage Paul's position was not the dominant voice or perspective within primitive Christianity.

Paul's own personal development and his social identity were characterised by plurality and social identity complexity. Although we cannot be completely certain about it, as a result of the uncertainty with regard to the historicity of Acts, amongst other things, there seems to be at least some consensus that Paul grew up in Tarsus as a Diaspora Jew (Ac 22:3). Only at a later stage in his life, Paul went to Jerusalem and was further educated in a more conservative Judean environment under Rabban Gamalial, who was well-known as a teacher of Jewish oral law. A few years after the death of Christ, on the road to Damascus, Paul experienced some form of revelation that he expresses as a radical changing moment in his life, which progressively changed his social identity and his sense of inclusiveness (Acts 9, and so forth; Phil 3:7-9; see Karyakina 2014:106-114). We could thus argue that Paul's social identity might have been rather complex in nature because of the diverse contexts to which he was exposed (Figure 5).

Paul himself thus once embodied an exclusive Judean identity as he expresses in Philippians 3:4-6. But in Galatians 1:11-12, Paul explains in the strongest possible way that he received a revelation from above that opened his eyes and radically transformed the way in which he came to see the boundary lines between insiders and outsiders. Based on this revelation, and his (or God's) vision of reconciliation (2 Cor 5:17), Paul embodied an ethos of inclusivity that transcended boundaries instead of drawing boundaries.

In Galatians 3:28 Paul states that: 'There is neither Jew nor Greek, there is no longer slave or free, there is no longer male and female, for all of you are one in Christ Jesus.' The particular concern for Paul revolved around the matter of social cohesion and inclusivity, around the transcendence of social and other boundaries that have become a possibility (even necessity) in Christ. Hans Dieter Betz (1987:181) agrees that it was in fact Paul's whole goal in Galatians to steer towards this point, namely that 'all of you are one'. In Paul's mind, a believer has received a brand new recreated status before God and man, a status that created a new symbolic world where the man-made boundaries no longer play the same role as before. This new symbolic universe does not only feature within the community of faith. Betz (1987:190) is correct that ' $[t]$ here can be no doubt that Paul's statements have social and political implications of even a revolutionary dimension'. The old social boundary lines between Jews and Greeks, slave and free have been abolished. This vision calls for a new integrative social reality (merger

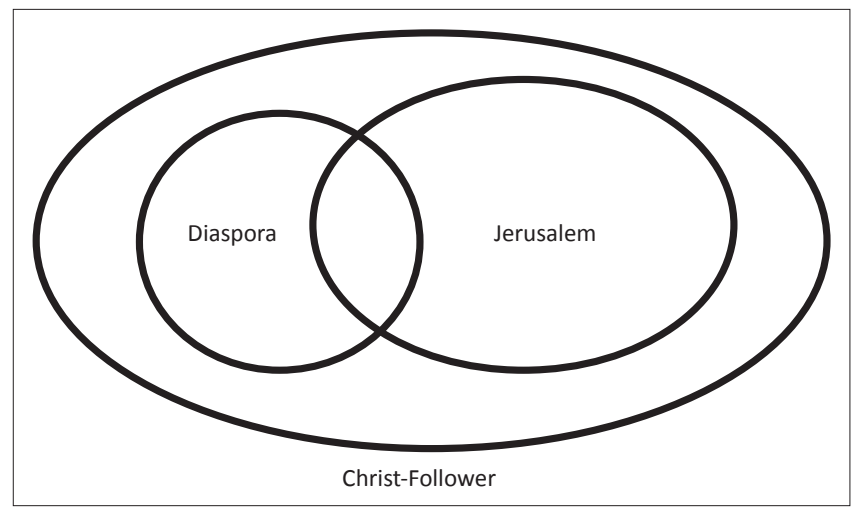

Author's own work

FIGURE 5: Paul and the merger model. 
model) that takes seriously God's plan for a new creation (Gl 6:15). From a critical discourse analytical perspective (see Locke 2004), it is important to look at the words Paul used to express this new understanding of reality. Consumers and producers of text can either reproduce or transform the hegemony discourses of society. Paul's language illustrates that he transformed the status quo of discourses of his day. In Paul's view, this new dispensation calls for a kind of 'death' to the old paradigm of thinking towards a new paradigm where one is in effect 'dead' to the man-made sociocultural and religious distinctions/categories of 'this world' (Gl 2:19) (Betz 1987:190).

It could be argued that this early Christian vision presented a revolutionary alternative to the sociocultural and religious hegemony of the day, especially from a temple-oriented Judean point of view, as discussed previously. This vision represented and embodied the heart of a new movement where boundaries are transcended, and where the good is done to all people (Gl 6:10). Within this movement there should be a revolutionary space where these boundaries are transcended and something of this new symbolic worldview seen in action. Practically, in Paul's day and in his mind it meant that the old categories of distinguishing between insiders and outsiders should be drawn in a new inclusive way by means of an overarching identity in Christ (cf. Gl 3:26-29). The Judean ethnicity markers that distinguished insiders and outsiders - for instance circumcision - can no longer function as exclusive boundary markers (cf. Gl 5:6; 6:15; Rm 2:25-29; Col 2:11; 3:11; Eph 2:11-22). When these boundary markers are eliminated, a new form of equality is established between groups that formerly differentiated themselves from each other. Betz (1987) argues convincingly that:

This program seems to have been taken over by primitive Christianity, where in its mission the formerly exclusively Jewish prerogatives were extended to Gentile believers by simultaneously removing the Jewish external religious and social distinctions. (p. 191)

This vision proclaims a new form of unity of mankind by means of the abolition of cultural barriers that separated people from each other in the past (Betz 1987:192). For Paul, the truth of the gospel $(\mathrm{Gl} 2: 5,14)$ was brought about by a new eschatological reality and a new creation, which inevitably implied unrestricted social intercourse and the visible expression of that reality in practice (Hansen 2010:71). This implied that people from different social strata, cultures and backgrounds would be seen as being part of the same social group: the ecclesia. Clearly, this vision would fit into the merger paradigm discussed previously, which represents a high level of social identity complexity. Different groups are reconciled to each other in a new over-arching identity that incorporates the rich diversity of plurality within the new community. To this end, Paul uses linguistic expressions that represent this merger character; language like 'new creation', 'brothers and sisters', 'all of you are one'; and he rejects language and practices that break down this unity (cf. Gl 3:38;
1 Cor 12:13; Col 3:11). Those who live contrary to these values are pseudoadelfoi, that is, false brothers. As a result of Paul's seemingly high level of social identity complexity, it was at times easy for him to become a Jew for the Jews and a Greek for the Greeks, illustrating the flexibility that he had, which enabled him to move between different self-positions with the purpose of bringing about corporate solidarity and otherregard (cf. 1 Cor 9:19-23).

However, his oscillation between these different selfpositions did not imply compartmentalisation, but was driven by an inclusive missional motivation (cf. 1 Cor 9:19;

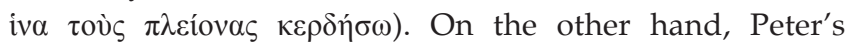
compartmentalised behaviour led to division and to resegregation, and for this reason Peter's oscillation between his Antioch-Self and his Jerusalem-Self could not be seen as characteristic of the merger position. Because of Paul's social identity complexity and his inclusive theology, he could deal with different dimensions and aspects of his polyphonic self. He had experiences of being a Judean in different contexts that ranged from having received an education in Tarsus as a Diaspora Jew, being exposed to Hellenistic philosophy and being a rather conservative Pharisee in Jerusalem as well as a Christ-following Jew with an openness to include non-Jews. This does not represent compartmentalising social identity, but rather a merger social identity characterised by social identity complexity. This is particularly inspiring, even today.

\section{Conclusion}

In the previous discussion, we have illustrated that much can still be done to develop a 'thick description' of early Christian identity construction and ethos with the help of social scientific perspectives and models. One such thick description that could open up new paths to think about the way in which early Christ-followers might have transcended boundaries is to make use of Social Identity Complexity Theory. In this article there was only space to touch on the surface level of the text and the topic as such. What we have learnt from this analysis is that there are many ways in which our social identity can be structured. Our social identity can be high or low in social identity complexity. People with a high level of social identity complexity tend to be more inclusive of outgroups, according to Roccas and Brewer (2002). From a cursory analysis of the Pauline texts as case study, it seems that Paul had a high level of social identity complexity that enabled him to transcend social boundaries and facilitate a higher level of inclusiveness. Paul was rather critical of Peter at one stage in history, as a result of Peter's compartmentalisation that functioned in a dominating way and brought about re-segregation rather than reconciliation. Paul's baptismal unity formula in Galatians 3:28, which states that all believers are one in Christ, irrespective of whether a person is a Jew or a Greek, free person or slave, created new language and metaphors that transformed rather than maintained the social boundaries and social hegemony of his day. This is particularly inspiring, even today. 


\section{Acknowledgements Competing interests}

The author declares that he has no financial or personal relationship(s) that may have inappropriately influenced him in writing this article.

\section{References}

Arnal, W.A., 2009, 'Jesus as Battleground in a period of cultural complexity', in W. Blanton, J.G. Crossley \& H. Moxness (eds.), pp. 99-117, Jesus beyond nationalism, Equinox, London.

Betz, H., 1987, Galatians: A commentary on Paul's letter to the Churches in Galatia, Fortress, Augsburg. (Hermeneia commentary series)

Elliott, J.H., 2007, 'Jesus the Israelite was neither a "Jew" nor a "Christian": On correcting misleading nomenclature', Journal for the study of the historical Jesus 5(2), 119-154. http://dx.doi.org/10.1177/1476869007079741

Esler, P.F., 2003, Conflict and identity in Romans, Fortress Press, Minneapolis.

Fairclough, N., 1995, Critical discourse analysis, Longman, London.

Frey, J., 2012, 'The Jewishness of Paul', in O. Wischmeyer (ed.), Paul: Life, setting, work, letters, pp. 57-95, T\&T Clark, London.

Hanson, B., 2010, All of you are one: The social vision of Gal 3:28, 1 Cor 12:13; $\mathrm{Col}$ 3:11, T\&T Clark, London.

Karyakina, M., 2014, 'Social values of heavenly society: The concepts of honor and identity in Paul's letter to the Philippians', unpublished PhD thesis, Department New Testament Studies, University of Pretoria.
Kok, J., 2008, 'Siekte en gebrokenheid teenoor genesing en restorasie in Johannes', Doktorale proefskrif, Departement Nuwe-Testamentiese Wetenskap, Universiteit van Pretoria.

Kok, J. \& Van Eck, E. (eds.), 2012, Unlocking the world of Jesus, Biblaridion, Pretoria.

Kok, J. \& Roth, D.T., 2014, 'Sensitivity towards outsiders and the dynamic relationship between mission and ethics/ethos', in J. Kok, T. Nicklas, D.T. Roth \& C.M. Hays (eds.), Sensitivity towards Outsiders: Exploring the Dynamic relationship between mission and ethics in the New Testament and Early Christianity, pp. 1-26, Mohr Siebeck, Tuebingen. (WUNT 2).

Locke, T., 2004, Critical discourse analysis, Continuum, London.

Malina, B. \& Rohrbaugh, R., 1992, Social Science commentary on the Synoptic Gospels, Fortress Press, Minneapolis.

Neyrey, J.H., 1991, The social world of Luke-Acts: Models for interpretation, Hendrikson, Peabody.

Roccas, S., \& Brewer, M.B., 2002, 'Social identity complexity', Personality and Social Psychology Review 6(2), 88-106. http://dx.doi.org/10.1207/ S15327957PSPR0602_01

Schmid, K., \& Hewstone, M., 2011, 'Social Identity Complexity: Theoretical implications for the Social Psychology of intergroup relations', in R.M. Kramer, G.J. Leonardell \& R.W. Livingston (eds.), Social cognition, Social identity, and intergroup relations: A Festschrift in honor of Marilynn B. Brewer, pp. 77-102, Psychology Press, New York.

Trebilco, P., 2013, 'Creativity at the boundary: Features of the linguistic and conceptual construction of outsiders in the New Testament', paper presented at the SNTS meeting, Murdoch University, Perth, 23rd-26th July.

Tucker, B.J., \& Baker, C.A. (eds.), 2014, T\&T Clark handbook to social identity in the New Testament, T\&T Clark, New York.

Wolter, M., 2006, "'Let no one seek his own, but each one the other's" (1 Corinthians 10, 24): Pauline ethics according to 1 Corinthians', in J.G. van der Watt (ed.), Identity ethics and ethos in the New Testament, pp. 199-218, Walter De Gruyter, Berlin. http://dx.doi.org/10.1515/9783110893939.199 